\title{
Soil Patterns Associated with the Major Geological Units of the Kruger National Park
}

\author{
F.J. VENTER
}

Venter, F.J. 1986. Soil patterns associated with the major geological units of the Kruger National Park. - Koedoe 29: 125-138 Pretoria. ISSN 0075-6458.

The dominant soil types of the Kruger National Park and their interrelationships with parent material, topography and climate are discussed. The geogenetic and topogenetic nature of the soils are manifested in the strong correlations between recurrent soil patterns, major geological units and terrain morphology. The soils are categorised into seven major classes on the basis of the parent material from which they developed. General soil patterns within the major classes are discussed.

Key words: Soils, soil patterns, geology, vegetation, terrain units, Kruger National Park.

F.J. Venter, Department of Research and Information, Kruger National Park, Private Bag X402, Skukuza, 1350.

\section{Introduction}

The exceptional diversity of the biotic components of the Kruger National Park (KNP) ecosystem, are founded to a great extent on the variety of rock and soil types encountered in the Kruger National Park. The strong correlation between geology and soils accentuate the geogenetic nature of the soils, which is to be expected of a relatively young erosion surface such as the Lowveld. While the role of soil properties in plant and animal ecology decreases in extremely wet and dry climates, it is of vital importance in areas with moderate climates such as the Kruger National Park. Properties such as soil depth, texture and structure which regulate the effectiveness of rainfall and determine the quantity and availability of soil water, together with nutritional properties, are strikingly reflected in the biotic components. Thus, abiotic components form an integral and complex part of KNP ecology.

The soils have been categorised into seven major classes on the basis of the parent material from which they originated and general soil patterns within

ISSN 0075-6458 = Koedoe $29(1986)$ 
each class are discussed. Within every class many variations from the general pattern occur which fall beyond the scope of this paper, and only variations which are considered to be of ecological significance in size or intensity, are discussed.

The soils were classified into soil series according to the South African binomial soil classification system (MacVicar, De Villiers, Loxton, Verster, Lambrechts, Merryweather, Le Roux, Van Rooyen \& Harmse 1977). The names of soil series used are followed by an abbreviation which refers to the soil form to which the soil series belongs, as well as a number which distinguishes the specific soil series from other series in the soil form. However, recurring soil patterns, and not individual soil types, are the main point of focus in this paper.

\section{Soil Characteristics}

\section{Soils on Granitoid Basement Rocks}

Soils occur in distinctive catenary sequences on granitoid rocks in the Kruger National Park (Figs. 1-4). This is the result of mobilisation and eluviation of clay particles and soluble weathering products from porous soils in upland positions by rain water and lateral downward transportation of such constituents under the influence of gravitation to footslope positions where they are redeposited to form impermeable clay horizons. Groundwater which moves downslope under the influence of gravitation, is forced to the surface

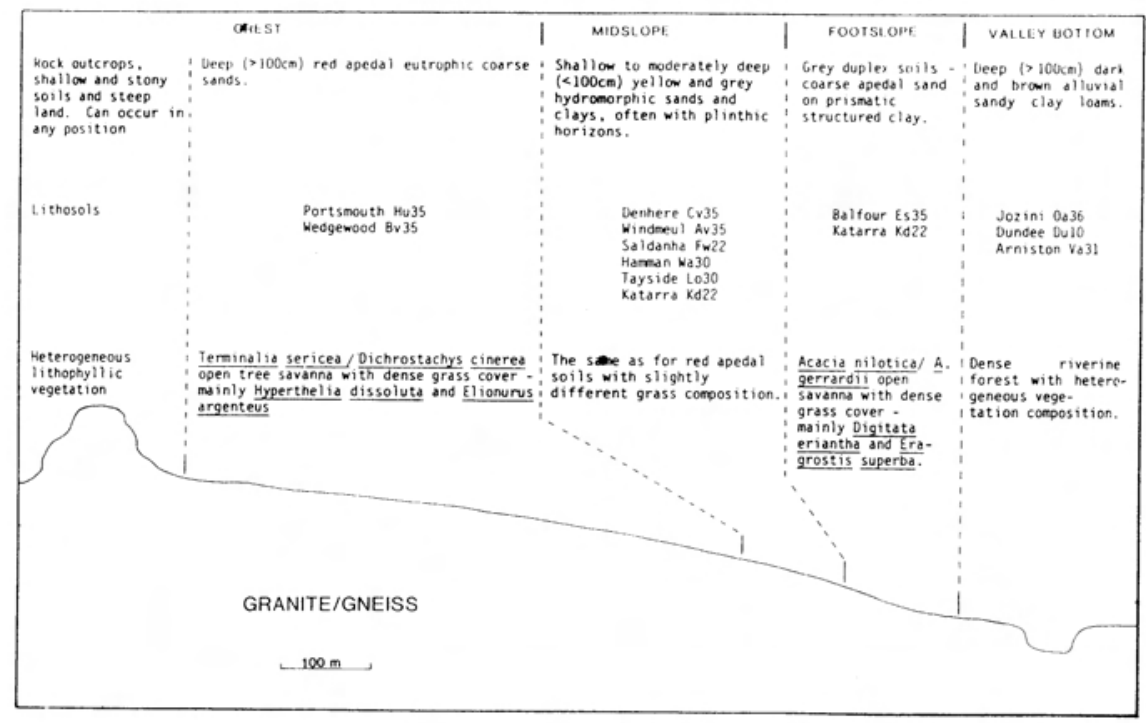

Fig. 1. Relationships between terrain morphology, sQils and vegetation on granite/gneiss in the Pretoriuskop area, southern Kruger National Park (Vegetation after Gertenbach 1983). Soil form symbols: Hu - Hutton, Bv - Bainsvlei, Cv Clovelly, Av - Avalon, Fw - Fernwood, Wa - Wasbank, Lo - Longlands, Kd Kroonstad, Es - Estcourt, Oa-Oakleaf, Du - Dundee, Va-Valsrivier. 
as soon as it reaches these positions, thus forming waterlogged zones in the rainy season (seepage lines) which more or less follow the contours.

Although the general sequence from crest to valley bottom (i.e. sandy, hydromorphic, duplex, alluvial) (Figs. 1 \& 2) are found throughout the region, many different soil types and patterns occur. These differences are related to differences in annual precipitation and geology.

In the Pretoriuskop area, which lies within the $600 \mathrm{~mm}-750 \mathrm{~mm}$ per annum rainfall zone, hydromorphic and duplex soils form narrow strips along drainage lines (Fig. 1) with the result that crests are large and are generally occupied by red apedal sands (Harmse \& Van Wyk 1972). Greater hydromorphy along midslopes are reflected in a greater variety of soil types, and series with mottled or hardpan ferricrete subsoils are abundant. The latter soils are usually scarce or absent in areas where the rainfall is below 650 mm per annum (Figs. 2-4).

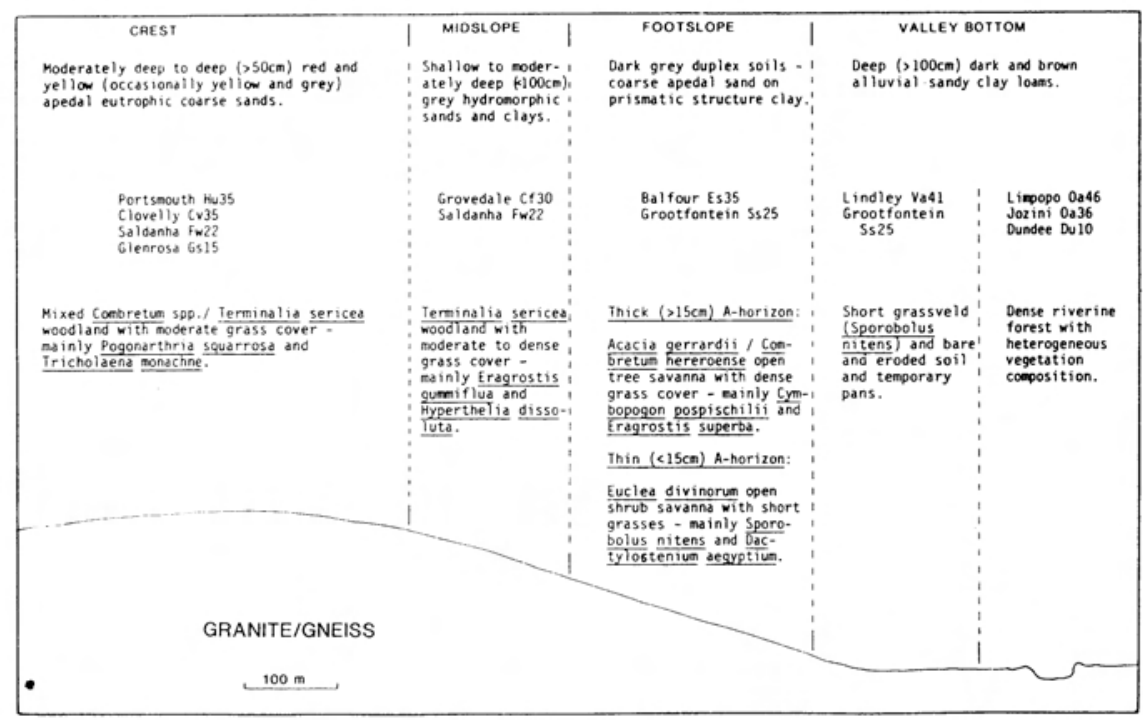

Fig. 2. Relationships between terrain morphology, soils and vegetation on granite/gneiss in the Hlangulene area, central Kruger National Park (Vegetation after Gertenbach 1983). Soil form symbols: Hu - Hutton, Cv - Clovelly, Fw - Fernwood, Gs - Glenrosa, Cf - Cartref, Es - Estcourt, Ss - Sterkspruit, Va - Valsrivier, Oa Oakleaf, Du - Dundee.

The typical catenary sequence associated with granite-gneiss is best developed in the area which lies within the $500 \mathrm{~mm}-600 \mathrm{~mm}$ per annum zone. In the Hlangulene area (Fig. 2) large, open footslopes with predominantly duplex soils occur. Midslopes, which are situated directly above footslopes, consist of a thin belt of grey hydromorphic sands which is generally known as the seepage line or Terminalia sericea belt. In this area the seepage line is very conspicuous. 
In the northern areas where the annual precipitation is below $500 \mathrm{~mm}$, catenary sequences tend to become faint due to less hydromorphy. The soils tend to be shallow and they lack distinctive morphology which is characteristic of soils in wet climates.

Metamorphic rocks such as amphybolite and schist, which are relics of older greenstone belts within the granitoid rocks, crop out more frequently in the northern areas. They form red sandy clay loams of the Hutton, Shortlands, Glenrosa and Swartland soil forms. These areas are usually less undulating and they lack the distinctive catenary sequence of soils as found in pure granite-gneiss areas. They also have much lower drainage densities than the surrounding granitic areas.

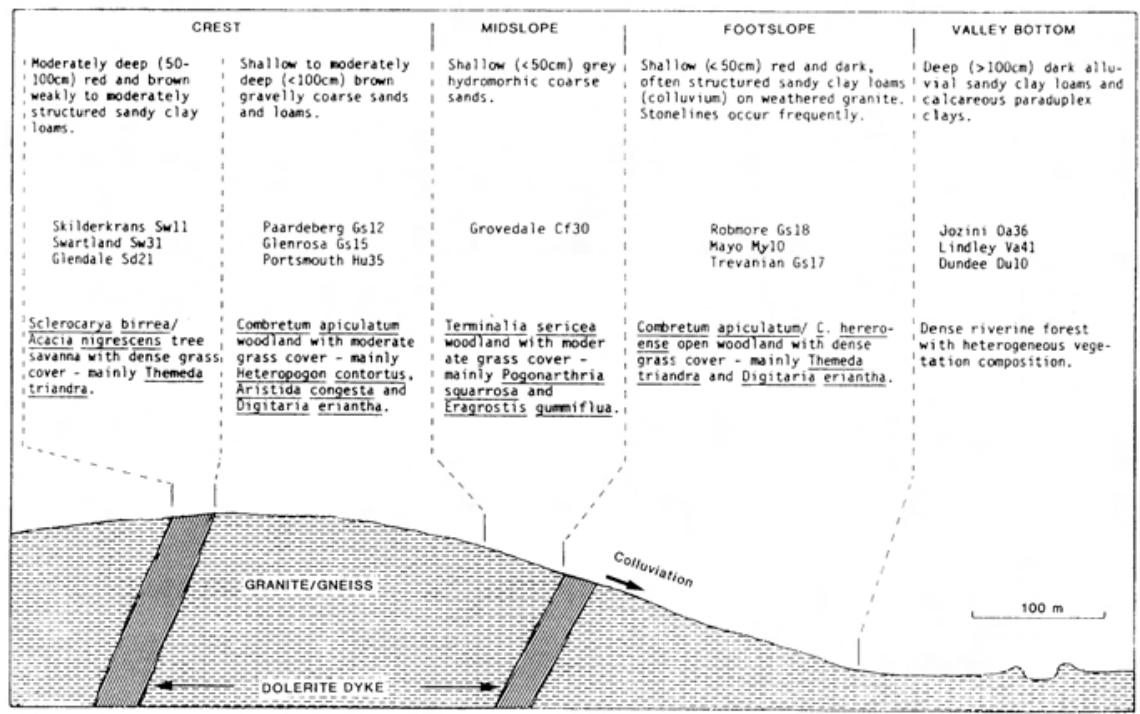

Fig. 3. Relationships between terrain morphology, soils and vegetation on granite/gneiss with a high density of dolerite dykes in the Mzanzene area, central Kruger National Park (Vegetation after Gertenbach 1983). Soil form symbols: Sw Swartland, Sd - Shortlands, Gs - Glenrosa, Hu - Hutton, Cf - Cartref, Ms - Mispah, $\mathrm{Oa}$ - Oakleaf, Va-Valsrivier, Du-Dundee.

Dolerite dykes of Karoo age often abound in the basement rocks. They weather into clayey structured fertile soils and their presence causes a marked change in soil patterns (Figs. $3 \& 4$ ). In certain areas they occur in dense swarms and form complex soil patterns which differ from normal granite-gneiss patterns. Many soils in these areas are from binary origin due to colluviation of doleritic material over weathered basement rocks (Fig. 3) and stonelines consisting of half rounded quartz pebbles occur frequently in the solum.

\section{Soils on Argillaceous Sedimentary Rocks}

Sediments of the Ecca Group (i.e. grey mudstones, shales and micaceous 


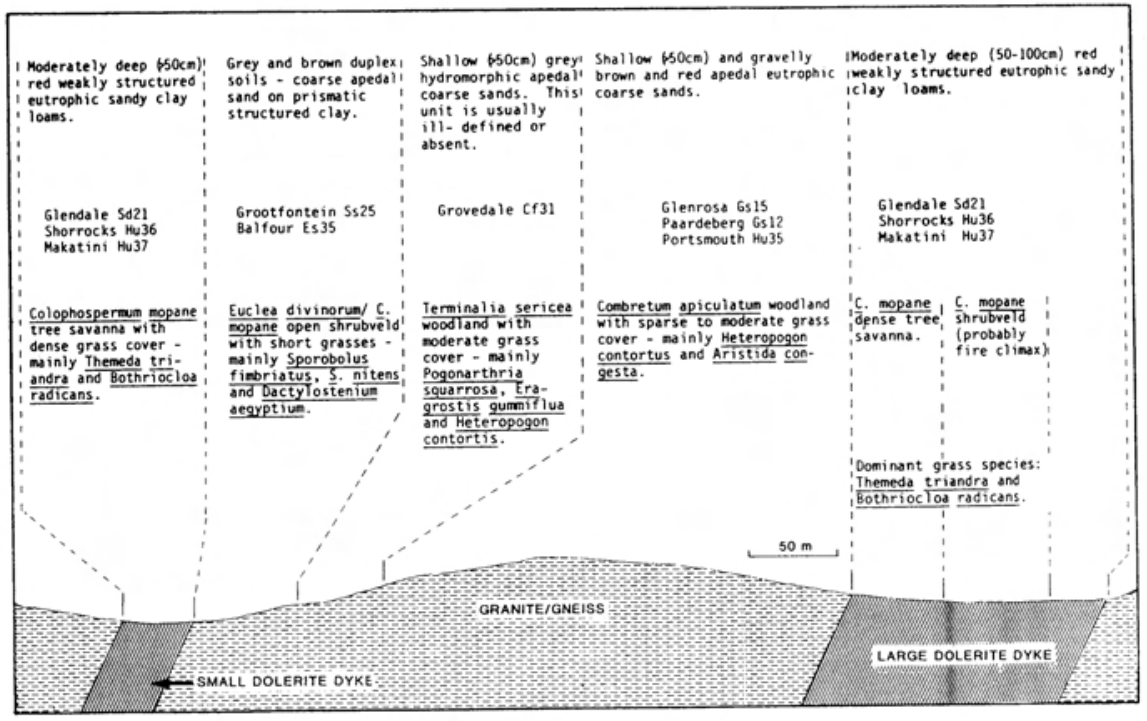

Fig. 4. Relationships between terrain morphology, soils and vegetation on granite/gneiss with a high density of dolerite dykes in the northern Kruger National Park (Vegetation after Gertenbach 1983). Soil form symbols: Sd - Shortlands, Hu Hutton, Ss - Sterkspruit, Es - Estcourt, Cf - Cartref, Gs - Glenrosa.

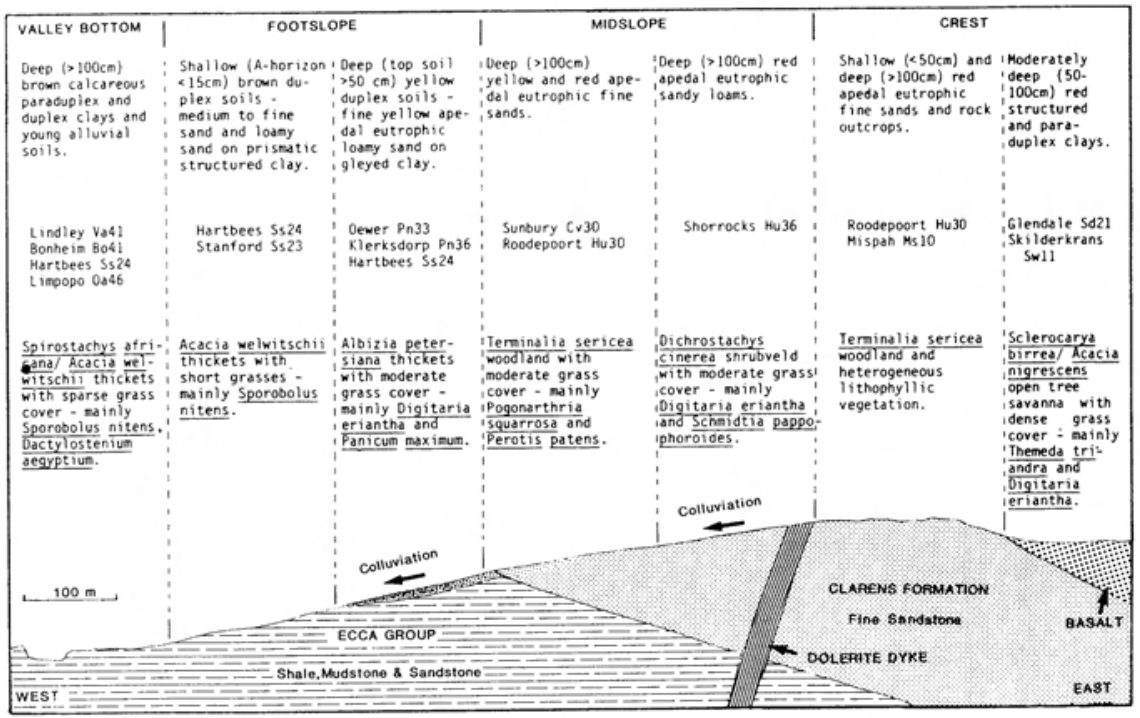

Fig. 5. Relationships between geology, terrain morphology, soils and vegetation on Karoo sedimentary rocks in the Nkaya Pan area, central Kruger National Park (Vegetation after Coetzee 1983). Soil form symbols: Va - Valsrivier, Bo-Bonheim, Ss - Sterkspruit, Oa - Oakleaf, Pn - Pinedene, Hu - Hutton, Cv - Clovelly, Ms Mispah, Sd - Shortlands, Sw - Swartland. 
sand- and siltstones) are easily weathered and form relatively large areas of brown and grey, clayey, structured soils in the southern and central districts of the KNP, as well as in the extreme north. In the southern and central districts duplex soils are dominant (Fig. 5), while in the Punda Maria area para-duplex soils such as the Nyoka and Swartland series of the Swartland form (Harmse, Van Wyk \& Gertenbach 1974) are usually the dominant soil series.

Rocks 'of the Ecca Group weather negatively with regard to the adjoining sandstone of the Clarens Formation. This caused the formation of a distinctive scarp through incision of the Madzaringwe stream in the northern KNP (Fig. 6), and areas with colluvial binary soils in the southern areas (Fig. $5)$.

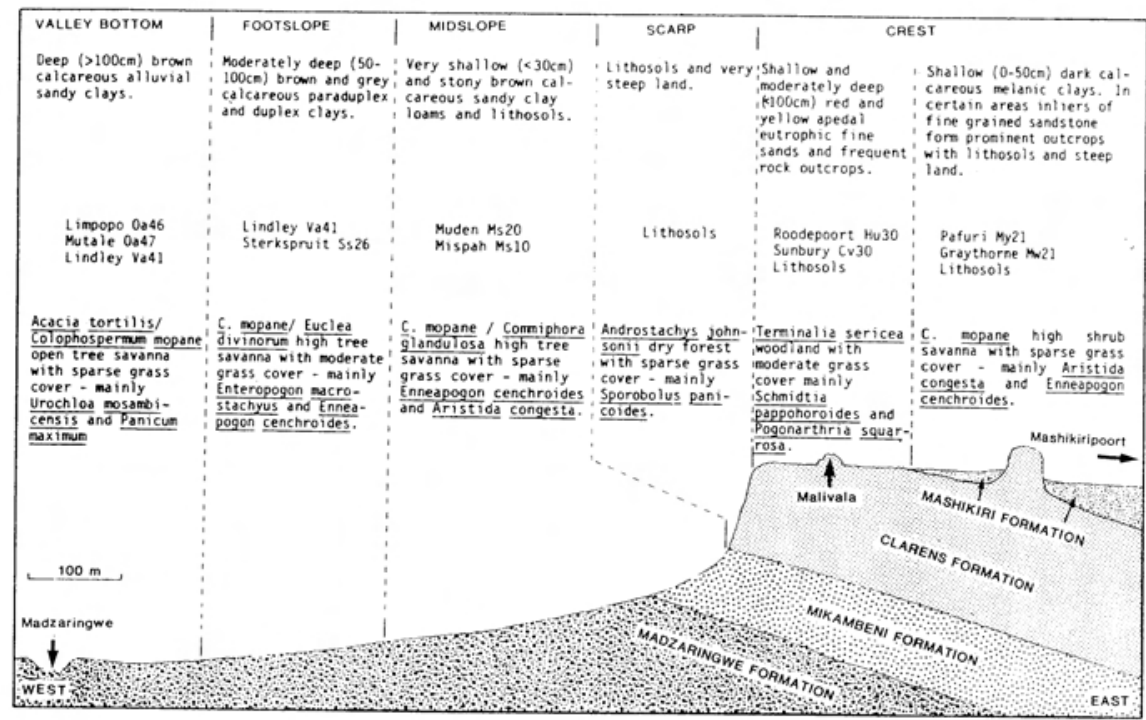

Fig. 6. Relationships between geology, terrain morphology, soils and vegetation in the Madzaringwe area, northern Kruger Natjonal Park (Vegetation after Van Rooyen 1978). Soil form symbols: Oa - Oakleaf, Va - Valsrivier, Sw - Swartland, Ms Mispah, $\mathrm{Hu}$ - Hutton, $\mathrm{Cv}$ - Clovelly, My - Mayo, Mw - Milkwood.

Duplex soils usually contain a fair amount of soluble salts and exchangeable sodium, making it chemically and physically inaccessible to many plant species. However, species which are adapted to halomorphic conditions, thrive on these soils. These areas are also favoured by many game species, especially those preferring short grass conditions. This phenomenon is also due to the fact that these soils contain considerable amounts of most of the nutrients required by animals (Venter 1981). The occurrence of many seasonal pans due to the sodic and dispersed condition of the soils make these areas even more acceptable to game. For the same reasons (dispersed clay and poor infiltration) these areas have a serious erosion hazard. 


\section{Soils on Arenaceous Sedimentary Rocks}

Soils derived from sandstones and quartzites of the Clarens Formation and Soutpansberg Group usually have sandy textures due to the lack of weatherable minerals in the predominantly quartz-rich parent materials (Figs. 5 \& 7). In areas with normal topography these soils can reach depths of up to 3 metres. More frequently, however, areas underlain by these rocks are characterized by prominent hills or inselbergs with shallow skeletal soils and rock outcrops, the only deep soils occurring in pockets between rock outcrops. This is especially true of the Punda Maria/Pafuri area where they occur most extensively and give rise to outstanding scenery.

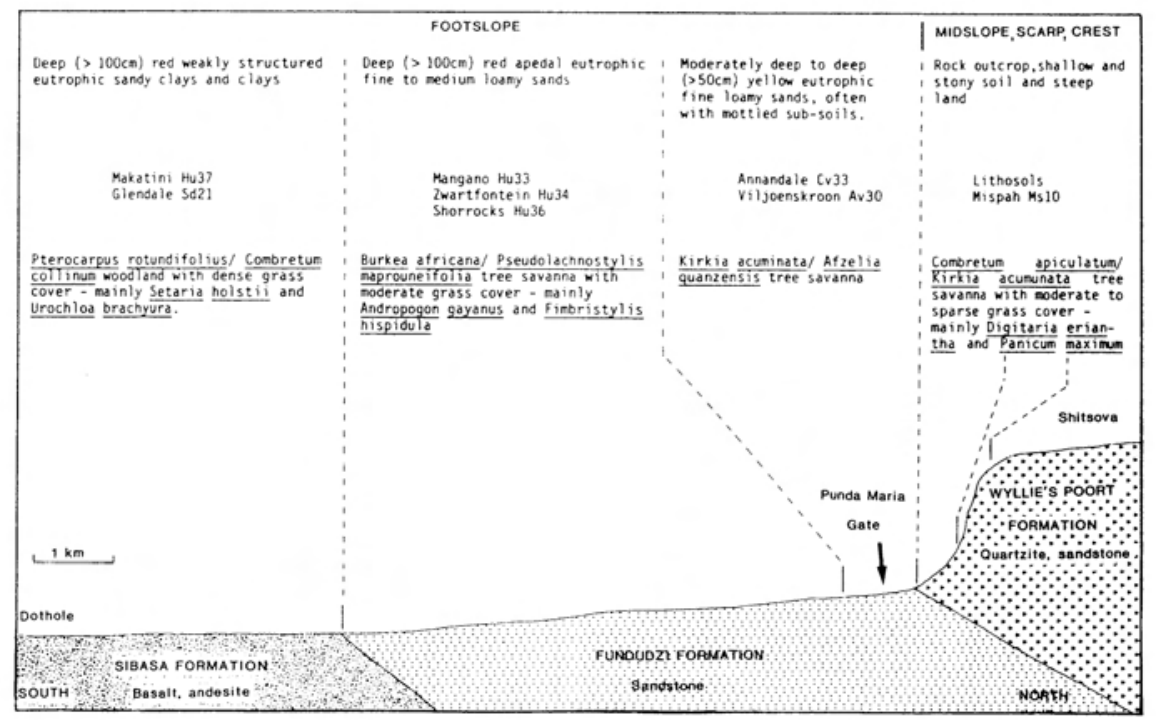

Fig. 7. Relationships between geology, terrain morphology, soils and vegetation on rocks of the Soutpansberg Group, Punda Maria area, northern Kruger National Park (Vegetation after Van Rooyen 1978 and Gertenbach 1983). Soil form symbols: Hu Hutton, Sd - Shortlands, Cv - Clovelly, Av - Avalon, Ms - Mispah.

An admixture of weathered products derived from dolerite dykes which often occur in the sedimentary rocks is reflected by finer textured soils and different vegetâtion compositions (Fig. 5).

\section{Soils on Mafic Igneous Rocks}

The composition of the mineral assemblage of the different basic igneous rocks which crop out in the KNP, have markedly influenced the soils which evolved from these rocks (Table 1). The stability of different clay minerals in soil regimes are dependent on the presence and constant supply of specific clay forming elements which are derived from parent rocks through weathering under specific climates. Most of the ecologically essential soil properties are determined by the type and quantity of clay minerals present in the soil. 


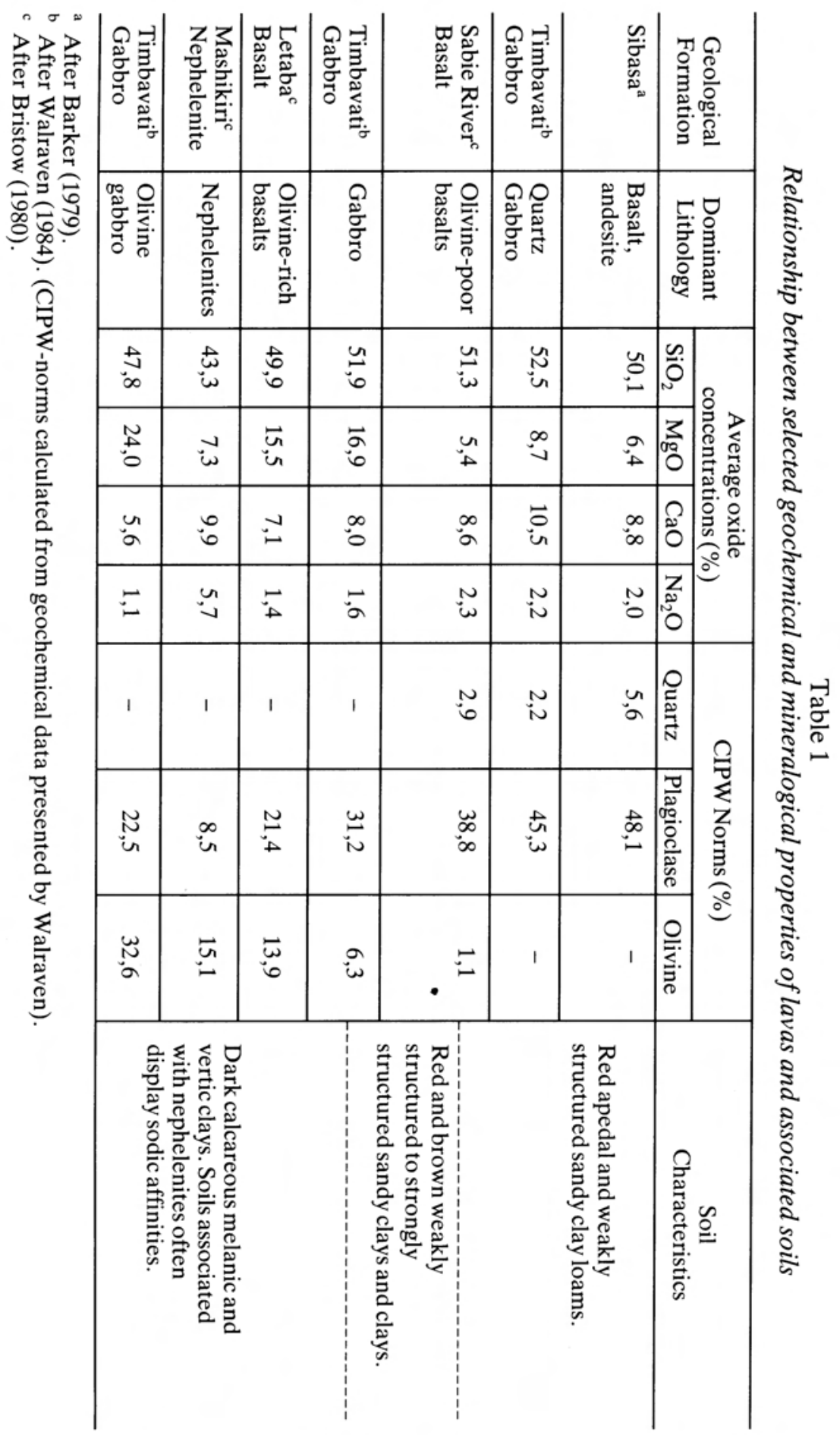


Table 1 shows that levels of olivine in basic lavas are apparently the most important parameter for the development of vertic (swell-shrink) properties in soils. Since most of the modal olivines in the lavas of the KNP are Fo-normative (Bristow 1980; Walraven 1984), this phenomenon is in accordance with findings of Kittrick (1971a, b), Weaver, Jackson \& Syers (1971), and Mohr, Van Baren \& Van Schuylenborgh (1972) who rate the presence of $\mathrm{Mg}^{2+}$ in soil regimes high for the synthesis of smectite (swelling) clay minerals.

Soutpansberg lavas: The basaltic and andesitic lavas south of Punda Maria weather into red weakly structured and apedal sandy clay loams (Fig. 7; Table 1). The soils are deep in the western region where the rainfall is approximately $600 \mathrm{~mm}$ per annum (Gertenbach 1980 ), but become shallow as the rainfall decreases towards the east.

Mashikiri Nephelinite: The nephelinite basalts (Cleverly \& Bristow 1979) tend to form dark calcareous clayey soils (Fig. 8, Table 1), which are locally extremely stony and lithosolic (Fraser 1983). On the plains north of Dzundwini the dominant soil series are Rensburg (Rg20) and Arcadia (Ar40), while in the Kaleka area (Fraser 1983) the dominant series are Arcadia (Ar40) and Bonheim (Bo41). In the former area the soils contain considerable amounts of soluble salts and exchangeable sodium and the vegetation displays halophyllic affinities (Van Rooyen 1978).

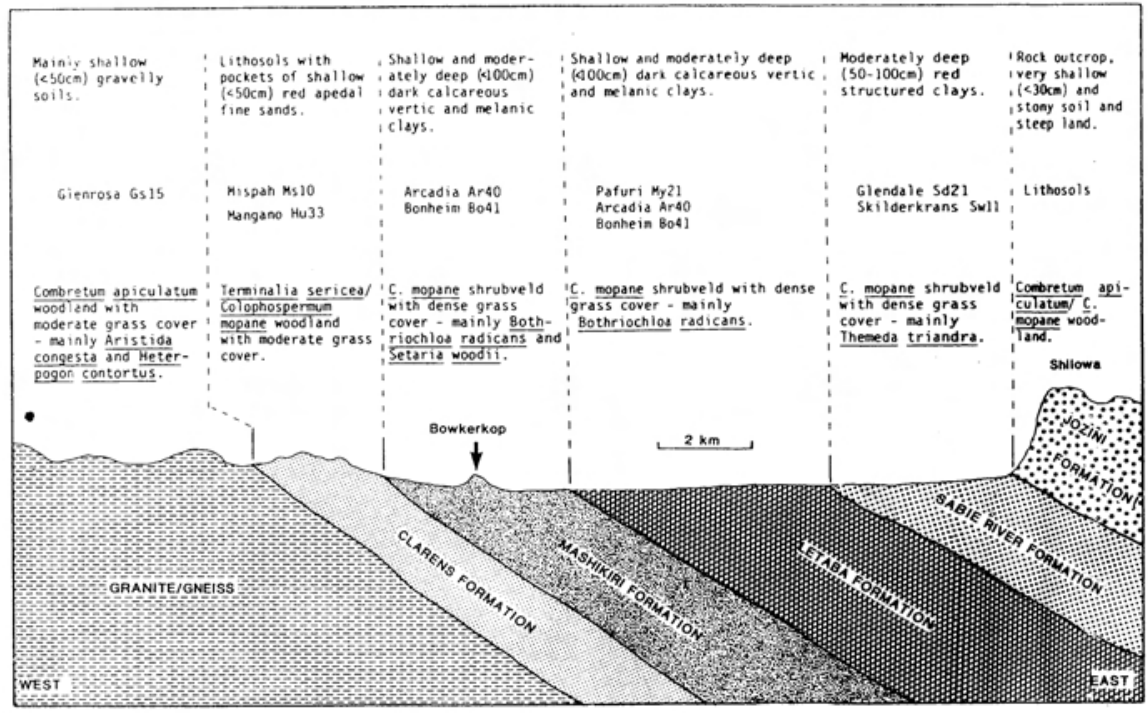

Fig. 8. Cross section of Karoo rocks in the Mooiplaas region, northern Kruger National Park, showing relationships between geology, soils, terrain morphology and vegetation (After Fraser, Van Rooyen \& Verster 1985). Soil form symbols: Gs Glenrosa, Ms - Mispah, Hu - Hutton, Ar - Arcadia, Bo - Bonheim, My - Mayo, Sd Shortlands, Sw - Swartland.

Letaba Basalt: The olivine-rich (Cleverly \& Bristow 1979) basalts are easily weathered and have formed large areas of dark clays (Figs. $8 \&$ 9; Table 1) 
which generally contain an excessive amount of $\mathrm{CaCO}_{3}$. In some places cementation of soil particles have been sufficient as to form continuous layers of hardpan calcrete. These are occasionally exposed where the topsoil has been stripped by erosion in incised areas.

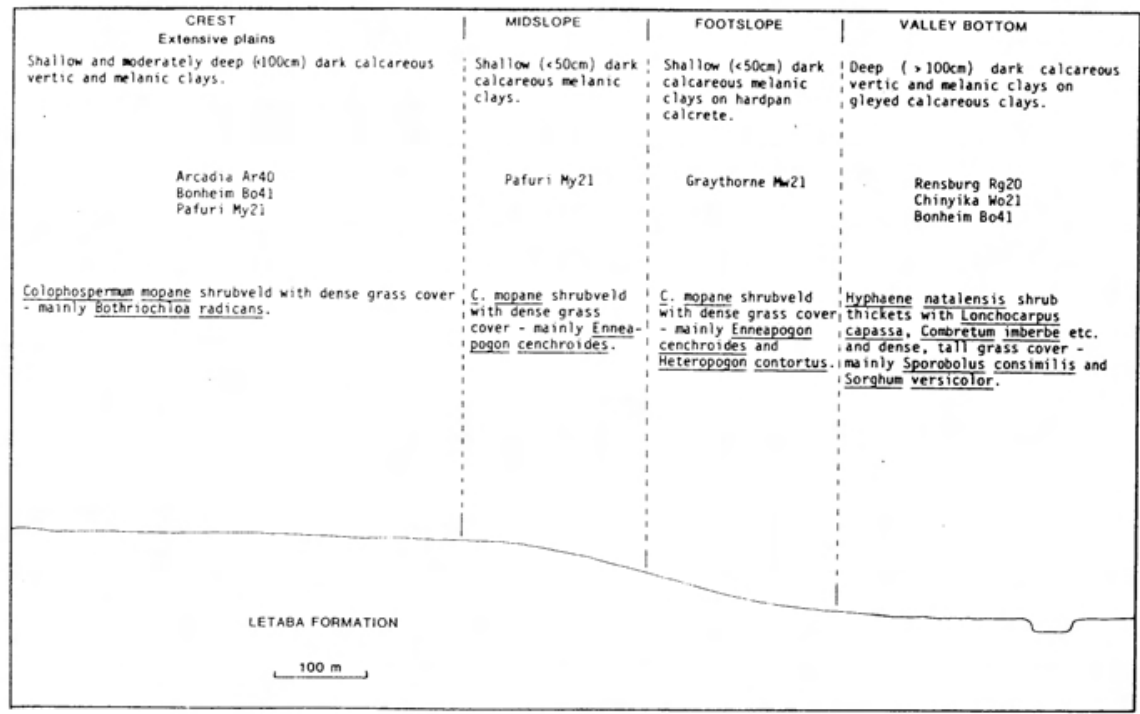

Fig. 9. Relationships between terrain morphology, soils and vegetation on the picrite basalts of the Letaba Basalt Formation in the Boyela region, northern Kruger National Park (Vegetation after Gertenbach 1983). Soil form symbols: Ar - Arcadia, Bo-Bonheim, My-Mayo, Mw - Milkwood, Rg-Rensburg, Wo-Willowbrook.

Sabie River Basalt: The olivine-poor basalts of the Sabie River Formation (Cleverly \& Bristow 1979) are as easily weathered as the picrite basalts, and there is no topographic difference between the two (Fig. 8). However, the Sabie River basalts contain less olivine and more quartz than the picrites (Table 1) and produce less weathering products suitable for the synthesis of smectite clay minerals on weathering. The subsequent synthesis of kaolinitic clay minerals instead have resulted in the formation of red structured and pedocutanic sandy clays which are seldom calcareous.

Timbavati Gabbro: The soils associated with the gabbro sills are strong correlatives of the soils derived from basalt (Table 1). On quartz gabbro and gabbro (Walraven 1984), soils which are similar to those of the Sabie River basalts are found, while olivine gabbro has formed soils similar to those found on the picrites with the exception that calcrete does not occur so extensively (Fig. 11).

Along the contacts between gabbro intrusions and granite, extensive colluviation of gabbroic material over weathered granite has resulted in the formation of binary soils (in which stonelines frequently occur) on downslope positions (Fig. 11). Where granite is topographically higher than gabbro, colluviation does not occur so extensively. On the contrary, the gabbro seems 


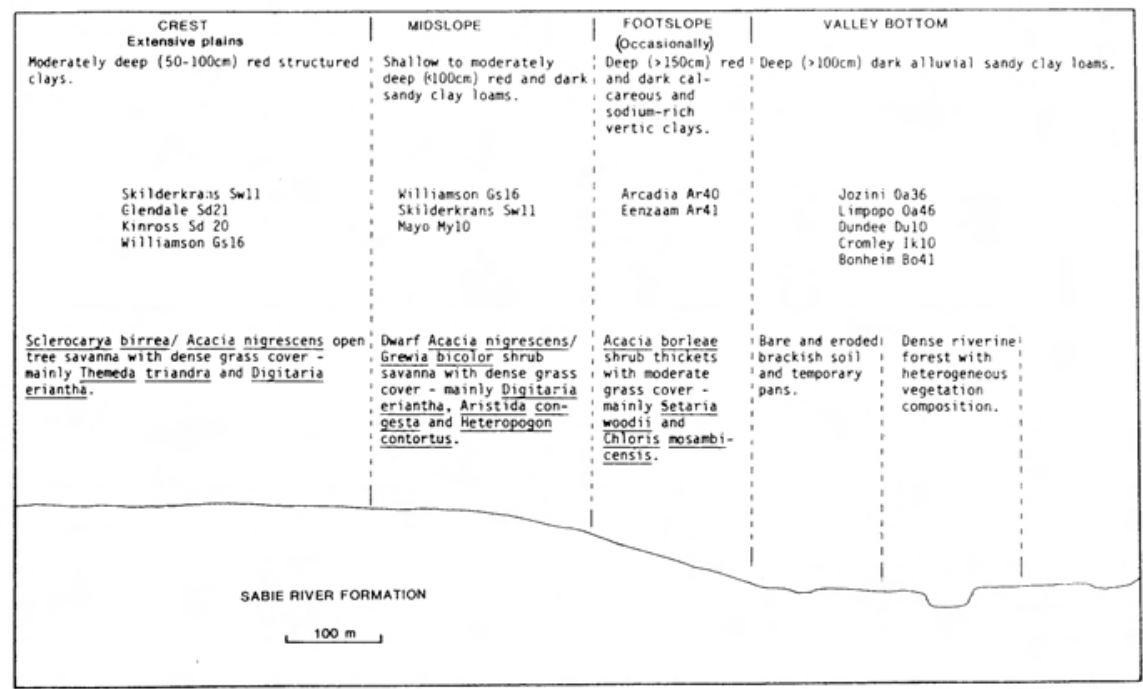

Fig. 10. Relationships between terrain morphology, soils and vegetation on the Sabie River Basalt Formation in the Sweni region, Central District, Kruger National Park (Vegetation after Gertenbach 1983). Soil form symbols: Sw - Swartland, Sd Shortlands, Gs-Glenrosa, My-Mayo, Ar-Arcadia, Oa-Oakleaf, Du-Dundee, Ik -Inhoek, Bo-Bonheim.

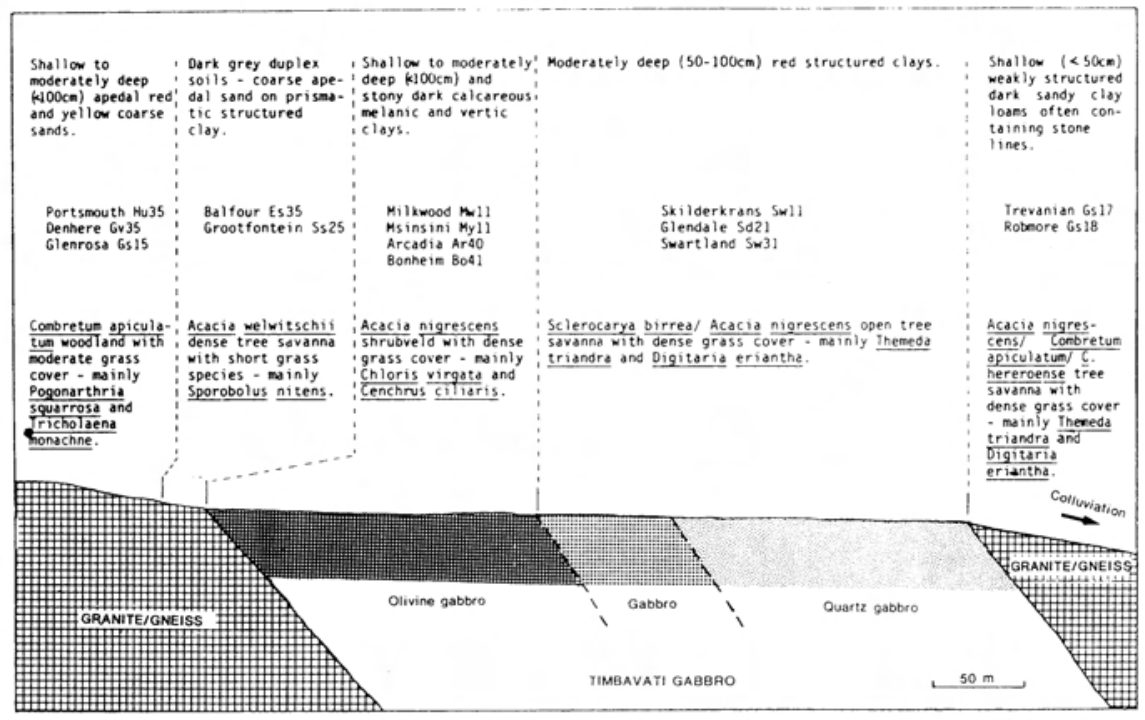

Fig. 11. Relationships between geology, soils and vegetation on Timbavati Gabbro sills in the Central District, Kruger National Park (Vegetation after Gertenbach 1983). Soil form symbols: Hu - Hutton, Cv - Clovelly, Gs - Glenrosa, Es - Estcourt, Ss - Sterkspruit, Mw - Milkwood, My - Mayo, Ar - Arcadia, Bo - Bonheim, Sw Swartland, Sd - Shortlands.

to be acting as a barrier to underground water movement with a resultant buildup of sodium and soluble salts (derived from sodium-rich feldspars in 
granite) and the formation of sodic duplex soils (Fig. 11).

\section{Soils on Felsic Igneous Rocks}

Jozini Rhyolite and Tshokwane Granophyre: The rhyolites and granophyres are extremely resistant to weathering and hills consisting mainly of lithosolic soils and rock outcrops are associated with them (Fig. 8). Mispah (Ms10) is the dominant soil series. Characteristic of these areas is the fact that very little or no saprolite occurs between soil and unweathered rock, whereas most of the other soils in the KNP usually grade into saprolite which could be several metres thick before solid rock is encountered.

\section{Soils on Tertiary and Quarternary Sediments}

Deep sandy soils are found along the eastern boundary of the KNP at Pumbe and Nwambia, the latter area being the larger of the two. The soils are predominantly red along crests and midslopes and grade into yellow-brown soils along footslopes (Fig. 12). The sands, which are several metres thick in some places, overlie well rounded boulders and cobbles, sandstone and limestone of the Malvernia Formation (Schutte 1972). A general characteristic of these areas is the occurrence of several large pans. In the Pumbe area most of the pans are excluded from the KNP by the boundary fence. In the valleys of drainage channels which incised the Nwambia plateau and where these rocks are exposed, shallow soils of the Glenrosa and Mispah forms are found.

\section{Soils of Alluvial Deposits}

Young alluvium occurs along most of the drainage lines in the KNP, the

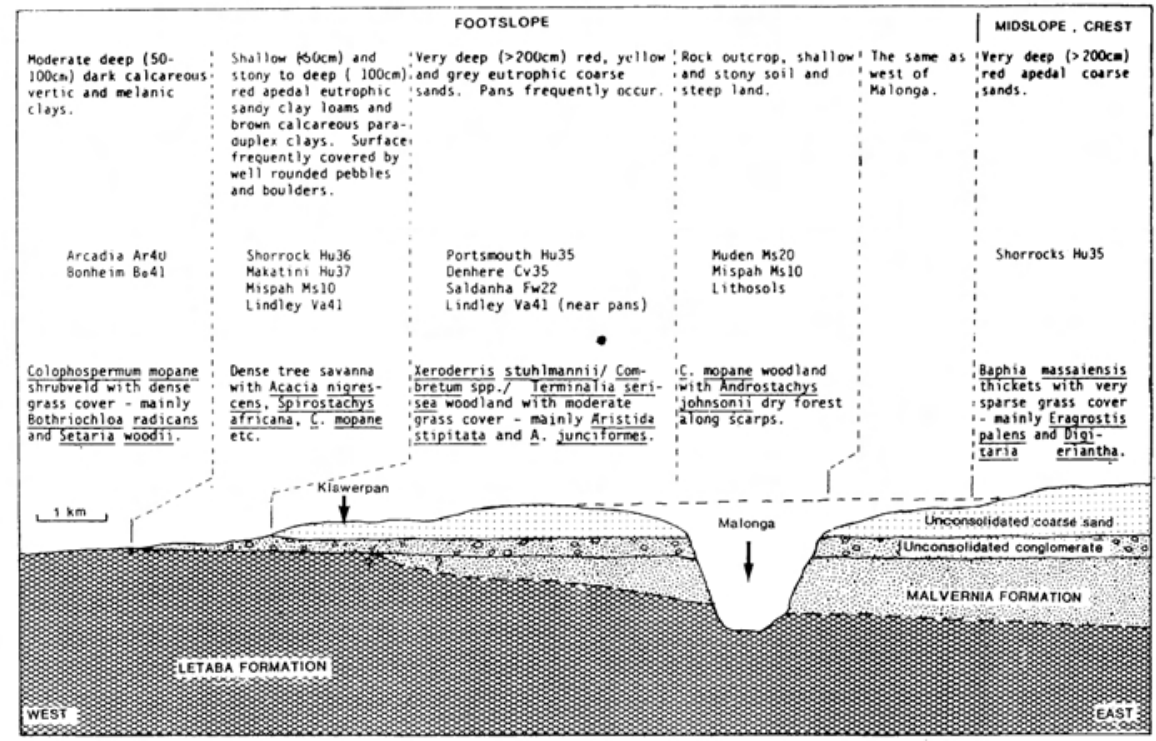

Fig. 12. Relationships between geology, terrain morphology, soils and vegetation on Tertiary and Quaternary Sediments in the Nwambia region, northern Kruger National Park (Vegetation after Van Rooyen 1978). Soils form symbols: Ar Arcadia, Bo - Bonheim, Hu - Hutton, Ms - Mispah, Va - Valsrivier, Cv - Clovelly, Fw-Fernwood. 
extent of which increases as the size of drainage lines increases. Most of the soils belong to the Oakleaf, Valsrivier, Inhoek and Dundee soil forms, and many different series, sometimes occurring in complex patterns, are present. Older river terraces and gravels also occur along some of the major rivers.

The most extensive alluvial deposits are found along the Limpopo and Luvuvhu rivers in the northern Kruger National Park. The sediments flanking the Limpopo River are mostly sandy while those along the Luvuvhu consist of deep red clay loam.

\section{Acknowledgements}

I thank Prof. T.H. van Rooyen, Drs. S.C.J. Joubert, M.G.L. Mills and J.W. Bristow, and Messrs. W.P.D. Gertenbach and I.J. Whyte for reading the manuscript and making valuable suggestions. Merle Whyte kindly typed part of the manuscript in her private time and Rinza Venter helped with the figures. The work was done under the auspices of the National Parks Board of Trustees.

\section{REFERENCES}

BARKER, O.B. 1979. A contribution to the geology of the Soutpansberg Group, Waterberg Supergroup, northern Transvaal. M.Sc. thesis. University of the Witwatersrand, Johannesburg.

BRISTOW, J.W. 1980. The geochronology and geochemistry of Karoo volcanics in the Lebombo and adjacent areas. Ph.D. thesis. University of Cape Town, Cape Town.

CLEVERLY, R.W. and J.W. BRISTOW. 1979. Revised volcanic stratrigraphy of the Lebombo monocline. Trans. geol. Soc. S. Afr. 82 (2): 227-230.

COETZEE, B.J. 1983. Phytosociology, vegetation structure and landscapes of the Central District, Kruger National Park, South Africa. Dissertationes

- Botanicae. Cramer and Vaduz.

FRASER, S.W. 1983. Soil studies of the Mooiplaas-Mahlangeni Region, Central Kruger National Park. M.Sc. thesis, University of South Africa, Pretoria.

FRASER, S.W., T.H. VAN ROOYEN and E. VERSTER, 1985. Quantitative criteria for distinguishing melanic from vertic soil horizons in the Central Kruger National Park. S. Afr. J. Plant Soil 2: 171-174.

GERTENBACH, W.P.D. 1980. Rainfall patterns in the Kruger National Park. Koedoe 23: 35-43.

GERTENBACH, W.P.D. 1983. Landscapes of the Kruger National Park. Koedoe 26: 9-121.

HARMSE, H.J. VON M. and P. VAN WYK. 1972. Verkenningsgrondkaart van die Suidelike Distrik van die Nasionale Krugerwildtuin. Unpublished map. University of Potchefstroom for C.H.E., Potchefstroom.

HARMSE, H.J. VON M., P. VAN WYK and W.P.D. GERTENBACH. 1974. Verkenningsgrondkaart van die noordelike gedeelte van die 
Krugerwildtuin. Unpublished map. University of Potchefstroom for C.H.E., Potchefstroom.

KITTRICK, J.A. 1971a. Montmorillonite equilibria and the weathering environment. Soil Sci. Soc. Amer. Proc. 35: 815-820.

KITTRICK, J.A. 1971b. Stability of montmorillonites: II. Aberdeen montmorillonite. Soil Sci. Soc. Amer. Proc. 35: 820-823.

MACVICAR, C.N., J.M. DE VILLIERS, R.F. LOXTON, E. VERSTER, J.J.N. LAMBRECHTS, F.R. MERRYWEATHER, J. LE ROUX, T.H. VAN ROOYEN and H.J. VON M. HARMSE. 1977. Soil classification: $A$ binomial system for South Africa. Sci. Bull. No. 390, Dept. Agric., Pretoria.

MOHR, E.C.J., F.A. VAN BAREN and S.J. VAN SCHUYLENBORGH. 1972. Tropical Soils. The Hague: Mouton-Ichtiar Baru van Hoeve.

SCHUTTE, I.C. 1972. 'n Nuwe voorkoms van die Formasie Malvernia suid van Pafuri, Nasionale Krugerwildtuin. Ann. geol. Surv. S. Afr. 9: 83-84.

VAN ROOYEN, N. 1978. ' $n$ Ekologiese studie van die plantgemeenskappe van die Punda Milia-Pafuri-Wambiyagebied in die Nasionale Krugerwildtuin. M.Sc. thesis. University of Pretoria, Pretoria.

VENTER, F.J. 1981. Grondtipes van die Swenispruit-opvanggebied. M.Sc. thesis, University of Potchefstroom for C.H.E., Potchefstroom.

WALRAVEN, F. 1984. Geochemistry of the Timbavati Gabbro of the eastern Transvaal Lowveld, South Africa. Trans. geol. Soc. S. Afr. 87: 211-223.

WEAVER, R.M., M.L. JACKSON and J.K. SYERS. 1971. Magnesium and silicon activities in matrix solutions of montmorillonite-containing soils in relation to clay mineral stability. Soil Sci. Soc. Amer. Proc. 35: 823-830. 